\title{
The Role of School Principal Leadership in Implementation of Eco School Program as the Effort to Support Sustainable Development
}

\author{
Mirza Desfandi \\ Department of Geography Education, Universitas Syiah Kuala, \\ Banda Aceh \\ mirza_des@unsyiah.ac.id
}

Disman

Department of Economy Education, Universitas Pendidikan Indonesia

Bandung, Indonesia

\author{
Enok Maryani \\ Department of Geography Education, Universitas Pendidikan \\ Indonesia \\ Bandung, Indonesia
}

\begin{abstract}
Eco School is a program which aimed to create school members who are responsible in the effort to protect and manage school environment through good school governance to support sustainable development. School principal as leader in school should be able to play active and maximal role in the effort to create Eco School. This study is aimed to find out the role of school principal leadership in implementation of Eco School Program as the effort to support sustainable development. This study used qualitative approach and case study method. Data collection was done in 10 schools in Banda Aceh, Indonesia by involving 10 school principals as respondents. Result of study showed that school principal leadership has very vital role in school success in achieving the aim of Eco School Program. The result of study showed that school principal's care and commitment to environmental problems has big role toward development and implementation of environmental school policy. Based on this, as initial step to achieve the aim of Eco School Program then school principals should care and have high commitment toward environmental problems and they should become motivator and role model for all school members in order to have eco-friendly attitude and behavior.
\end{abstract}

Keyword-School principal leadership, Eco School, Sustainable development.

\section{INTRODUCTION}

Essentially, development can bring advancement to human, both technological advance and human civilization advance. On the other side, development also give negative effect. Human need toward natural source influence natural balance and result in natural destruction [1]. One of factor which cause environmental destruction (crisis) which is continually occurred so far is false point of view (paradigm) which refer to anthropocentrisms paradigm [2].

Anthropocentrisms paradigm view that human is the center of nature. Human is the most rational creature and they are free to exploit the nature for the sake of their needs and even for their egoism [3]. Human can do anything toward nature as long as it do not harm human interest. Individual with anthropocentrism paradigm preserve the environment just because the environment is very important for human survival and to improve human life quality[4]. Individual with anthropocentrism tendency argue that environment need to be protected because the value contained in environment is very useful for human survival. The interest of individual with anthropocentrism attitude toward natural environment more based on self-interest [5].

One commitment of international society in maintaining the earth from pollution and destruction is through the implementation of sustainable development [6]. Sustainable development concept should remove social inequality and environment destruction, while maintaining healthy economic bases [7].

One form of sustainable development implementation is through Eco School Program [8]. Eco School Program is implemented in Indonesia since 2006 by Ministry of Environmental Affairs and Ministry of Education and Culture. In Indonesia, Eco School Program which is called Adiwiyata Program. The aim of Eco School Program in Indonesia is to create school members who are responsible in the effort to protect and preserve environment through good school administration to support sustainable development [9].

To achieve the aim of Eco School Program, the role of all school members included school principal is very important. School principal as leader in school has strategic role the effort to create environmental cultured and cared school. Based on it, this study is aimed to find out how the role of school principal leadership in implementation of Eco School Program as the effort to support sustainable development.

\section{RESEARCH METHODOLOGY}

This study use qualitative approach with case study method. Data collection is done in 10 school which has National and Province Adiwiyata (Eco School) status in 
Banda Aceh, Indonesia by involving 10 school principals as respondent. Data collection is done through questionnaire and interview. Instrument of study is developed based on component and indicator of EcoSchool which is issued by Ministry of Environmental Affairs.

\section{LITERATURE REVIEW}

\section{A. Sustainable Development}

In the effort to face the rapid change and earth destruction as result of development pattern implemented by human for some decades which only considering economic aspect, therefore paradigm shift in development is needed, which is well-known as sustainable development. The development which had been run for the half of last century is equal, but it had gave negative effect to environment.

In sustainable development process, there is process of planned change, included natural source exploitation, investment direction, technology development orientation, and institution change which are in harmonies, and increase the present and future potency to fulfill community need and aspiration. Until now, sustainable development has role as concept, goal, and rapid change and now become main mission of international organization, national institution, organization, city and region continually [10]. Sustainable development is accepted widely as a policy and become the goal among many institutions which is related with the future of natural source development in the world [11].

\section{B. Eco School Program}

Eco Schools program was developed in 1994 on the basis of the need for involving young people in finding solutions to environmental and sustainable development challenges at the local level [12].

Eco School Program is implemented in elementary school, junior high school and senior high schools with the aim to develop environmental awareness, and to support environment management and sustainable development education [13]. Eco School program is based on interdisciplinary principle, comprehensive and systematical approach, future oriented, relate the local environmental problems to global environmental issue and decision making democratically toward environmental issue by combining cognitive, affective and aesthetic aspects [14].

When school had been registered to follow Eco School program, all school members commit to be involved actively in process of developing learning plan which focused on environmental problem and improve school environment [15].

\section{RESULT OF STUDY AND DISCUSSION}

In embodying Eco School Program, the serious effort is needed among all components included school principal, active role of school member (teachers, administrative staff and students) and community support in order to create clean, beauty, and comfort environment condition as embodiment of Eco School Program. In implementation of Eco School policy, the main implementer who is most decisive is school principal. The vital role of school principal based on finding of study are: (1) to formulate environmental school policy; (2) to implement environmental based curriculum; and (3) to develop eco-friendly school culture.

In initial step, each school which is participated in Eco School Program should form Eco School Team. Eco School Team consist of various elements, namely teachers, students and school committee. Eco School Team is leaded by a Eco School Program coordinator and appointed through Decree of School Principal. Based on finding of result, Eco School Team is leaded by a teacher and all school principals have role as coach in Eco School Team. In implementation of Eco School Program, school principal has role to arrange the planning, organize the program, direct the program, coordinate the program, implement supervision, and evaluate the implementation of Eco School Program.

A leader in Green School play six different roles, namely: aspirator, motivator, supporter, collaborator, learner, learning leader and manager/planner. The key actions are to educate, to create the curriculum surrounding environmental issues, and to promote professional development experience to staff so they also can be motivated to promote ecological problems in their life [16].

In formulating environmental school policy, school principal has role as concept maker. School principal' commitment toward environmental problems play big role in formulation of school policy. In implementation of environmental school policy which had been formulated and legitimated, the role of school principal's care and commitment toward the effort to overcome environmental problems which is started from school is very big. Based on finding of study, all school principals did not have high commitment toward environmental problems. One of indicator namely school policy which is articulated in vision, mission and aim of school have not been implemented optimally and not been socialized to all school members in each day and each week.

School principal's policies cannot be implemented without teachers' support. Family and community involvement also very important[17].Family give big influence to student behavior toward environment, in which the higher of family's education level, the more student will care about environment and participate actively [18]. Because of that to achieve the aim of Eco School Program, serious effort is needed among all components included school principal effort, active role of school members and community support in order to create individual who has ecological literacy and to create clean, beauty, safe, and comfort environmental condition as embodiment of Eco School Program.

Concerning environmental based curriculum implementation, school principal had made an effort to guide and direct curriculum development and instructional program and supervise its implementation. But that effort had still not been optimal, as a result of school principals' lack commitment and understanding toward environmental issues and because of their business. School principal commitment to always give great attention to implementation of 
environmental based curriculum very influential toward teachers' motivation.

School principal is demanded to more responsive and adaptive toward change through curriculum reorientation and restructuration particularly in syllabus and its implementation. As innovator, school principal should implement renewals of education implementation in school. School principal also should always supervise learning activity done by teachers, in order to make sure that they apply various approaches, strategies, methods, and learning techniques which involve students actively, and develop local issue in learning about environment.

School principal should always advocate teachers to be able to raise local environmental issue and problem in learning and relate it with learning material, as an effort to make learning close with local condition while train students to overcome environmental problems occurred in surrounding environment.

Environmental education learning in school which raise local issues give positive contribution to students' environmental activity and students' care about local environmental problems [19]. Developing local issue in learning about environment also is school contribution toward local environment. In Spain, some topics of environmental learning use global approach, but the most important thing is that environmental education should enable school to build relation with their local context, in which student and teacher involved in solving local environmental problem [20].

In the effort to build eco-friendly school culture, the role of school principal is very important. Based on finding of study, school principal had not play a role as model and motivator maximally in school. This based on indicator that all school principals not everyday supervise environmental behavior of all school members. This condition is a result of their business and lack of their motivation to build ecofriendly school culture. This is why school culture which is build in all schools studied had not been strong.

The change of school culture should started from school principal leadership. Therefore, school principals in EcoSchool should aware of the importance to build ecofriendly school culture and should aware that this is not detached from structure and pattern of their leadership style.

Based on this finding, the role of school principal to give role model, advise, and supervise students' behavior is very important, because the success of Eco School Program is collaboration of all school members, so it create environmental character and culture for school members whenever they are. If that character had been inculcated, then program and policy not become a burden anymore. School principal as leader has great potency to strengthened and apply school culture aspects.

Eco School program give big influence to students' knowledge, but not give significant influence toward students' attitude and behavior. This particularly because of school principal leadership, school culture and orientation difference and the aim of school policy [21].
School principals should become guidance, role model and motivator for their subordinates and also students in doing various activities. School principals' enthusiasm in guiding students in environmental management activity can motivate students to participate actively in managing school environment. In the case of disciplinary matter, school principal is a role model for all school members, what is done by school principal become example which will be followed by all school members. Therefore, school principal should give good example to school members in various things, included in maintaining and preserving school environment.

\section{CONCLUSION AND SUGGESTION}

The role of school principal in implementation of Eco School Program is very important and strategic. Based on finding of study, school principal had not been able to play a role maximally in the effort to embody Eco School, that is school that care about environment and has environmental culture, as a result of lack of school principal's commitment and care toward environmental problems. Therefore, all school principals should have awareness that the problem is responsibility of all individual and institution, included educational institution. In global environmental which is in the crisis condition, school should be able to play a role in preserving and managing environment which is began from school environment as the effort to support sustainable development from local level. Then school principal should become guidance, role model and motivator for all subordinates and students in the effort to embody environmental culture and cared school.

\section{REFERENCES}

[1] Pitman, S.D \& Daniels, C.B, "Quantifying ecological literacy in an adult western community: The development and application of a new assessment tool and community standard," PLoS ONE 11(3):e0150648.doi:10.1371/journal.pone. 0150648. March 3, 2016.

[2] Keraf, A. S, "Etika lingkungan hidup," Jakarta: Penerbit Buku Kompas, 2010.

[3] Kortenkamp, K.V. \& Moore, C.F, "Ecocentrism and anthropocentrism: moral reasoning about ecological commons dilemmas," Journal of Environmental Psychology, Vol. 21, No. 3, 2001, pp. 261-272.

[4] Baltaci, F., Yirik, S., Sargi, S.A, \& Yumusak, A, "From the ecocentric and anthropocentric perspectives, a survey of future tourism entrepreneurs' attitudes toward environmental issues: sample of Akdeniz University," International Journal of Humanities and Social Science, Vol. 5, No. 1; January 2015, pp. 139-143.

[5] Thompson, S. C. G, \& Barton, M. A, "Ecocentric and anthropocentric attitudes toward the environment," Journal of Environmental Psychology, 14, 1994, pp.149-157.

[6] Ozsoy, S., Ertepinar, H \& Saglam, N, "Can Eco-Schools improve elementary school students' environmental literacy levels?," AsiaPacific Forum on Science Learning and Teaching, Vol. 13 Issue 2/December 2012.

[7] Harris, J.M, "Basic principles of sustainable development," Medford MA: Global Development and Environment Institute, Tufts University, 2000.

[8] Zhang, J., Zhang, Z \& Zheng, Y, “An introduction of building green Schools," Journal of Sustainable Development, Vol. 2, No. 1, March 2009.

[9] National Adiwiyata Team, "Panduan Adiwiyata," Jakarta: Kementerian Lingkungan Hidup Republik Indonesia, 2012. 
[10] Kates, R.W, Parris, T.M, \& Leiserowitz, A.A, "What is sustainable development? goals, indicators, values, and practice," Journal of Environment: Science and Policy for Sustainable Development, Vol. 47, No. 3, 2005, pp. 8-21.

[11] Elliott, J.A, "An introduction to sustainable development," New York: Routledge, 2006.

[12] Ping, Y, "Global thinking, local action: a case study of the Green School Programme in China,". Thesis. Lund: Lund University, 2003.

[13] Ozturk, A, "The evaluation of success in raising environmental awareness through the musical instruments produced within the scope of Eco Schools Program implemented in Eskisehir," Procedia - Social and Behavioral Sciences, 51 ,2012, 828-831.

[14] Krnel, D \& Naglic, S, "Environmental literacy comparison between Eco-Schools and ordinary schools in Slovenia," Science Education International, Vol.20, No.1/2, December 2009, 5-24.

[15] Ward, K \& Schnack, K, "Perspectives on the Eco-Schools Programme: An environment education dialogue," Southern African Journal of Environmental Education, Vol. 20, 2003.

[16] Ackley, C.R,"Leadership in green schools: school principals as agents of social responsibility," Dissertation. Pennsylvania:The Pennsylvania State University, 2009.

[17] Fägerstam, E, "Children and young people's experience of the natural world: teachers' perceptions and observations," Australian Journal of Environmental Education, Volume 28, Issue 01, July 2012, pp. 1-16.

[18] Altin, A., Tecer, S., Tecer, L., Altin, S \& Kahraman, B.F,"Environmental awareness level of secondary school students: a case study in Balıkesir (Türkiye),"Procedia - Social and Behavioral Sciences, 141, 2014, pp. 1208 - 1214.

[19] Duvall, J., \& Zint, M, "A review of research on the effectiveness of environmental education in promoting intergenerational learning," The Journal of Environmental Education, 38, 2007, pp. 14-24,

[20] Conde, M.C \& Sanchez, J.L,"The school curriculum and environmental education: a school environmental audit experience. International Journal of Environmental \& Science Education, Vol. 5, No. 4, Oct 2010, pp. 477-494.

[21] Pauw, J.B \& Van Petegem, P, "The effect of flemish eco-schools on student environmental knowledge, attitudes, and affect," International Journal of Science Education, 33 (11): 2011, pp. 1513-1538. 